\title{
Fin-Tech UMKM untuk Stabilitas Sistem Keuangan Indonesia
}

\author{
Alfiatul Maulida \\ Universitas Sarjanawiayata Tamansiswa Yogyakarta
}

\begin{abstract}
MSMEs contributed quite a large contribution to Indonesia's GDP (Gross Domestic Product) at 36.82\%. When compared with the indicators in the assessment that support Indonesia's economic growth, this figure is very large. In addition to this, as many as $98.7 \%$ of Indonesian businesses are Micro businesses. Thus, with this amount, MSMEs can absorb $89.17 \%$ of the domestic workforce according to the Deputy Chairperson of the National Economy and Industry Committee. In 2017, MSMEs that had been online as much as 7.7\% and in 2019 targeted at $8 \%$ in the previous year, MSMEs had contributed significantly to Indonesia's economic growth. The nature of the research which is based on the philosophy of post positivity is used for the evaluation of natural tourist objects with researchers as a key instrument. Qualitative research is a method of data collection conducted by triangulation, data analysis is inductive, and the results of qualitative research emphasize the meaning of generalization. Analysis results prove the use of Fintech MSME is very effective and efficient will be able to support the Indonesian Financial System with various indicators that support Indonesia's economic growth.
\end{abstract}

Keyword: MSMEs, Financial Technology, Stabilization Financial System.

\section{Pendahuluan}

Semenjak beberapa tahun yang lalu, perkembangan teknologi di Indonesia sudah semakin pesat dari tahun ketahun. Perkembangan teknologi informasi sangat diterima oleh masyarakat Indonesia terutaman dari segi pengguna internet dari smartphone. Lebih dari 50\% atau sekitar 143 juta orang telah terhubung jaringan internet sepanjang 2017 (Asosiasi Penyelenggara Jasa Internet Indonesia, 2017).

Tahun 2019, pengguna internet di Indonesia meningkat sekitar 260.000 pengguna maka dapat di estimasikan bahwa pada tahun 2019 total penggunan internet sudah mencapai 143.260.000 pengguna dari estimasi populasi pada tahun 2019 sebanyak 269.536.482 (Versi Internet World Stats, 2019). Banyaknya masyarakat Indonesia yang sudah mengenal internet membuat teknologi dan reveolusi digital secara dramatis telah merubah lingkungan bisnis, khususnya industri jasa keuangan. Kemajuan teknologi dianggap mempermudah dan menyederhakan berbagai proses bisnis jika dilihat dari sudut pandang strategik. 
Pada tahun 2017, total transaksi Fintech Indonesia mencapai USD 15,02 Miliar.

Hal ini menunjukkan bahwa pengguna staetup lokal maupun asing sudang mulai tertarik dengan adanya revolusi pelayanan financial (Angraini dan Paolo, 2019). dimana pada tahun 2019 Negera Indonesia menduduki peringkat ke-5 pengguna internet di dunia. Hal tersebut membuktikan bahwa bukan hanya kaum milenial yang sudah mulai mengakses dan memanfaatkan internet tapi mayoritas masyarakat Indonesia dari berbagai kalangan dan status sosial. Berikut Top 20 negara yang menggunakan internet pada tahun 2019 versi Internet World Stats:

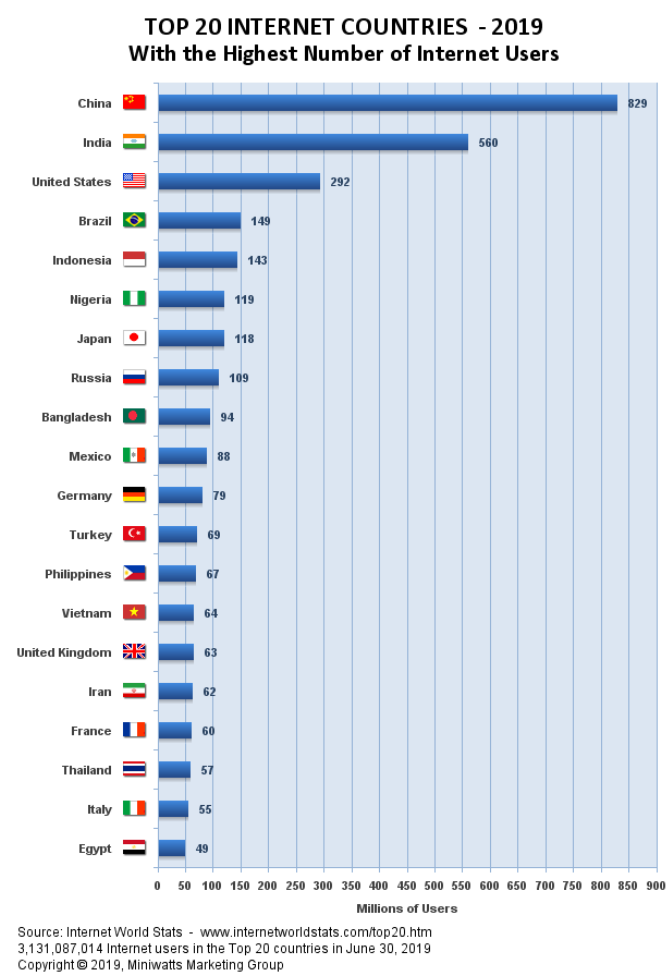

Gambar. Top 20 Internet Countries 2019

Acting Head of Financial Technology Bank Indonesia membagi Fintech yang ada di Indonesia menjadi 4 jenis:

1. Crowdfinding dan Peer to Peer Lending

2. Market Aggregator

3. Risk and Investment Managemant

4. Payment, settlement, and Clearing

Layanan keuangan digital Indonesia dilaksanakan dengan payung hukum Indonesia oleh Peraturan Otoritas Jasa Keuangan (POJK) Nomor 77/POJK01/2016, 
tentang Layanan Pinjam Meninjam Uang Berbasis Tekonologi Informasi (LPMUMBTI). OJK mengatur berbagai hal yang harus ditaati oleh penyelenggara bisnis pinjaman dari pengguna ke pengguna, atau yang disebut peer to peer lending. Sehingga pada akhirnya akan melindungi kepentingan konsumen terkait keamanan dana dan data, serta kepentingan nasional terkait pencegahan pencucian uang dan pendanaan terorisme, serta stabilitas sistem keuangan. Per tanggal 31 Mei 2019, perusahaan Fintech Lending yang berizin dan terdaftar di OJK sudah mencapai 115. Seperti, Danamas, Investree, Amartha, Dompet Kilat, KIMO, Tokomodal, dan UangTeman. Perusahaan tersebut merupakan perusahaan yang berizin dan terdaftar di OJK.

Adanya Fintech, memberikan dampak yang cukup besar bagi kalangan Usaha Mikro Kecil dan Menengah (UMKM) dimana sektor UMKM merupakan sektor tulang punggung riil bagi perekonomian Indonesia dan masih belum terlayani dengan baik untuk memenuhi kebutuhan UMKM untuk memperoleh tambahan pinjaman modal usaha. Berkembangnya Fintech di Indonesia memberikan harapan besar pagi pelaku UMKM yang tersebar di 17000 pulau wilayah Indonesia.

Indonesia merupakan salah satu negera yang memiliki UMKM terbanyak dibandingkan beberapa negara tetangga lain di Asia Tenggara. Menurut data kementrian Koperasi dan Usaha Kecil Menengah pada tahun 2015 terdapat 59,2 juta UMKM yang berada di Indonesiadan terus meningkat pesat pada tahun 2017. Dari banyaknya jumlah UMKM tersebut, 11 juta UMKM yang bisa menikmati layanan kredit perbankan (Imam, 2016). Pada tahun 2019, UMKM di Indonesia sudah mencapai 59.2 juta pelaku UMKM (Kemenkop UKM, 2019) dan 3.79 juta UMKM sudah Go Online. Hal ini membuktikan bahwa peluang UMKM untuk meningkatkan pertumbuhan perekonomian Indonesia sangat berperan penting untuk menstabilkan sistem keuangan negara. Angka 59.2 juta pelaku UMKM merupakan angka yang sangat besar untuk negara berkembang seperti ibu pertiwi. Indonesia merupakan negara dengan tingkat UMKM terbersar dibandingkan negara ASEAN lainnya.

UMKM turut serta memberikan kontribusi yang lumayan besar terhadap 
PDB (Produk Domestik Bruto) Indonesia yaitu 36.82\%. jika dibandingkan dengan indikator yang lain dalam penentuan pemberian kontribusi terhadap pertumbuhan perekonomian Indonesia maka angka tersebut sangat besar. Selain hal tersebut, sebanyak 98.7\% usaha warga Indonesia merupakan usaha Mikro. Maka, dengan jumlah tersebut UMKM dapat menyerap $89.17 \%$ tenaga kerja domestik menurut Wakil Ketua Komite Ekonomi dan Industri Nasional (Arif Budimanta, 2019). Pada tahun 2017, UMKM yang sudah go online sebanyak 7.7\% dan pada 2019 ditargetkan $8 \%$ pada tahun sebelumnya UMKM sudah memberikan kontribusi yang cukup besar bagi pertumbuhan perekonomian Indonesia. maka tidak dapat di pungkiri tahun selanjutnya kontribusi dari UMKM juga akan meningkat seiring dengan meningkatnya pelaku UMKM yang go online dimana pendapatan akan meningkat bahkan sampai 80\% (Delloite, 2015). UMKM dapat menjadi tulang punggung perekonomia Indonesia serta dapat meringankan tugas negara untuk mengentaskan kemiskinan dan meningkatkan nilai pendapatan perkapita daerah hingga personal. Maka pada akhirnya akan menstabilkan sistem keuangan Indonesia.

Stabilitas sistem keuangan merupakan suatu kondisi yang memungkinkan sistem keuangan nasional berfungsi secara efektif dan efisien serta mampu bertahan terhadap guncangan internal dan eksternal sehingga alokasi suberdana pendanaan atau pembiayaan dapat berkontribusi pada pertumbuhan dan stabilitas perekonomian nasional (PBI 16/11/PBI/2014 tentang Pengaturan dan Pengawasan Makroprudensial). Pentingnya menjaga stabilitas sistem keuangan negara, dibutuhkan sebuat kebijakan untuk memeliharanya. Kebijakan tersebut disebut kebijakan makroprudensial. Kebijakan makroprudential mempunyai fokus pada risiko dalam sistem keuangan secara keseluruhan, tidak hanya berfokus pada risiko masing-masing individu pelaku keuangan (Bank Indonesia).

Pengalaman krisis ekonomi tahun 1998, Bank Indonesia selaku otoritas pengelola moneter menempuh upaya preventif dengan memberlakukan prinsip kehati-hatian pada sistem keuangan untuk menjaga keseimbangan antara tujuan makroekonomi dan mikroekonomi (Kebiajakan Makro Preudensial). Demi mewujudkan tujuan macro-prudential dibutuhkan keseimbangan dalam sistem 
keungan yang berarti pelaku ekonomi di sistem keuangan harus stabil dan tahan terhadap krisis, maka disinilah pelaku usaha sangat dibutuhkan terutaman pelaku UMKM. Hal ini disebabkan UMKM merupakan usaha yang apling dekat dengan masyarakat umum. Adanya peran UMKM akan mengurangi risiko sistemik dan risiko konsentrasi karena modal usaha UMKM lebih kecil sehingga risiko konsentrasi tidak terlalu berdampak pada saat krisis.

Pelaku usaha 59.2 Juta dari \pm 265 juta jiwa, mempunyai pangsa pasar dan keuntungan usaha yang menjanjikan maka dapat merekrutnya calon pekerja. Membukan lapangan pekerjaan bagi masyarakat umum, akan membuat pelaku usaha dan masyarakat akan lebih sejahtera sehingga akan memiliki daya beli untuk memenuhi kebutuhan rumah tangga, menyimpan di bank, bahkan membeli saham atau produk investasi dari lembaga keuangan. Srtuktur sistem keuangan akan seimbang antara pelaku dengan modal besar dan pengusaha dengan skala kecil. Latar belakang diatas memberikan penulis inspirasi untuk menganalisis peran “Financial Technology UMKM Untuk Stabilitas Sistem Keuangan Indonesia". Tujuan penelitian ini adalah untuk menganalisis peran Financial Technology UMKM untuk Stabilitas Sistem Keuangan Indonesia.

\section{Tinjauan Pustaka}

\section{Definisi Fintech}

Fintech berasal dari istilah financial technology atau teknologi finansial. Menurut The National Digital Research Centre (NDRC), di dublin Rlandia, mendifinisikan Fintech sebgaai "Inovation in Financial Service” yang merupakan suatu inovasi pada sktor finansial yang mendapan sentuhan teknologi moderen. Menurut Oxford Dictionary dalam buku The Future of Fintech memberikan difinisi bahwa Fintech adalah (Nicoletti, 2017):

"Fintech is computer program and others technology used to support or enable banking and financial service”.

Financial technology merupakan sebuah inovasi dari sektor financial yang melibatkan model bisnis yang telah terintegrasi dengan teknologi yang dapat memberikan fasilitas peniadaan perartara, dapat megnubah cra perusaan yang sudah ada dalam membuat dan menyediakan produk dab layanan, dapat menaganni 
masalah privasi, regilasi, dan tantanga hukum, memberikan peluang untuk pertumbukan inklusif. Phillipon (2017) menggambarkan Fintech sebagai sebuah industri yang meliputi inovasi-inovasi digital dan inovasi model bisnis berbasis teknologi (Technology-enables business model) di sektor keuangan. Bank Sentral Amerika Serikat (2016), mendefinisikan fintench sebagai industri yang terdiri dari perusahaan dngan menggunakan tehnologi untuk membuat sistem keuangan dan layanan keuangan lebih efisien.

\section{Definisi Usahan Menengah Kecil dan Menengah(UMKM)}

UMKM berdasarkan asset dan omset per tahun, bahwa Usaha Mikro adalah usaha yang memiliki asset maksimal Rp 50.000.000,00 dan omset maksimal Rp 300.000.000,00. Usaha Kecil memiliki asset lebih dari Rp 50.000.000,00 sampai dengan Rp 500.000.000,00 dan omset lebih dari Rp 300.000.000,00 sampai dengan Rp 2.500.000.000,00. Sedangkan Usaha Menengah memiliki asset lebih dari Rp 500.000.000,00 sampai dengan Rp 10.000.000.000,00 dan omset lebih dari Rp 2.500.000.000,00 sampai dengan Rp 50.000.000.000,00. (Undang- Undang Nomor 20 Tahun 2008 tentang Usaha Mikro, Kecil dan Menengah).

Pada UU No. 20 Tahun 2008 tentang Usaha Kecil, Mikro dan Menengah atau yang biasa disingkat UMKM mempunyai definisi sebagai berikut:

a. Usaha Mikro adalah usaha produktif milik orang perorangan dan/atau badan usaha perorangan yang memenuhi kriteria Usaha Mikro sebagaimana diatur dalam UndangUndang yaitu memiliki kekayaan bersih paling banyak Rp50.000.000,00 (lima puluh juta rupiah) tidak termasuk tanah dan bangunan tempat usaha; atau memiliki hasil penjualan tahunan paling banyak Rp300.000.000,00 (tiga ratus juta rupiah).

b. Usaha Kecil adalah usaha ekonomi produktif yang berdiri sendiri, yang dilakukan oleh orang perorangan atau badan usaha yang bukan merupakan anak perusahaan atau bukan cabang perusahaan yang dimiliki, dikuasai, atau menjadi bagian baik langsung maupun tidak langsung dari Usaha Menengah atau Usaha Besar yang memenuhi kriteria Usaha Kecil sebagaimana dimaksud dalam Undang-Undang yaitu memiliki kekayaan bersih lebih dari Rp50.000.000,00 (lima puluh juta rupiah) sampai dengan paling banyak Rp500.000.000,00 (lima ratus juta rupiah) tidak termasuk tanah dan 
bangunan tempat usaha; atau memiliki hasil penjualan tahunan lebih dari Rp300.000.000,00 (tiga ratus juta rupiah) sampai dengan paling banyak Rp2.500.000.000,00 (dua milyar lima ratus juta rupiah).

Usaha Menengah adalah usaha ekonomi produktif yang berdiri sendiri, yang dilakukan oleh orang perorangan atau badan usaha yang bukan merupakan anak perusahaan atau cabang perusahaan yang dimiliki, dikuasai, atau menjadi bagian baik langsung maupun tidak langsung dengan Usaha Kecil atau Usaha Besar dengan jumlah kekayaan bersih atau hasil penjualan tahunan.

\section{Definisi Stabilitas Sistem Keuangan Indonesia}

Stabilitas sistem keuangan merupakan suatu kondisi yang memungkinkan sistem keuangan nasional berfungsi secara efektif dan efisien serta mampu bertahan terhadap guncangan internal dan eksternal sehingga alokasi suberdana pendanaan atau pembiayaan dapat berkontribusi pada pertumbuhan dan stabilitas perekonomian nasional (PBI 16/11/PBI/2014 tentang Pengaturan dan Pengawasan Makroprudensial). Pentingnya menjaga stabilitas sistem keuangan negara, dibutuhkan sebuat kebijakan untuk memeliharanya. Kebijakan tersebut disebut kebijakan makroprudensial. Kebijakan makroprudential mempunyai fokus pada risiko dalam sistem keuangan secara keseluruhan, tidak hanya berfokus pada risiko masing-masing individu pelaku keuangan (Bank Indonesia).

\section{Metode Penelitian}

\section{Sifat Penelitian}

Penelitian yang berlandasan filsafat postpositivme, digunakan untuk meneliti pada kondisi objek yang alamiah dengan peneliti sebagai instrument kunci, teknik Sifat penelitian ini menggunakan pendekatan kulitatif. Penelitian kualitatif adalah metode pengumpulan datanya dilakukan secara triangulasi, analisis datanya bersifat induktif, dan hasil peneltian kualitatif lebih menekankan makna dari pada generalisasi (Sugiono, 2008).

\section{Definisi Operasional}

Varibael independen dalam penelitian ini Stabilitas Sistem Keuangan dan Variabel dependen dalam penelitian ini adalah Fintech UMKM. 


\section{Populasi dan Sampel}

Populasi dalam penelitian ini adalah semua UMKM yang ada di Indonesia sedangkan sampel dari peneltian ini adalah UMKM yang ada di wilayah Yogyakarta.

\section{Teknik Analisis Data}

Teknik analisis data yang digunakan adalah analisis kualitatif. Langkahlangkah dalam analisis data kualitatif melalui empat proses yaitu mengumpulkan data, menyortir data yang tidak diperlukan, menyajikan dan menganalisis data wawancara maupun sekunder (literature review, study case, dan informasi media masa yang akurat), dan terakhir menyimpulkan data.

\section{Hasil Dan Pembahasan}

\section{Pengguna Fintech UMKM di daerah Yogyakarta}

Sebanyak 100.000 akses ke UangTeman dimana 60\% dari Yogyakarta dan 40\% dari Jawa tengan dan 30\% digunakan untuk kebutuhan modal usaha UMKM (Arifin, 2017). Pada tahun 2018, UMKM yang berada di DIY 285 ribu pelaku usaha. Jika pada setiap tahunnya terus meningkat UMKM yang go public maka tidak dapat dipungkiri pendapatan masyarakat akan meningkat dan semakin sejahtera dimana hal ini disebabkan oleh semakin terbukanya peluang perekrutan tenaga kerja sehingga masyarakat akan memperoleh pendapatan untuk emenuhi kebutuhan rumah tangga mereka, keinginan untuk menabing dibank akan semakin meningkat, begitupula bagi pemilik usaha, usaha mereka akan semakin meningkat, dapat bersaing dengan pelaku usaha tingkat lokal maupun internasional sehingga owner mampu berinvestasi di pasar modal, dan menabung uangnya di bank.

Benyaknya pelaku usaha di Yogyakarta yang sudah go public membuktikan tingginya antusias pelaku usaha UMKM Yogyakarta untuk beralih ke layanan financial (Financial Service) dimana lebih efektif dan efisien sehingga mampu mengurangi biaya yang harus dikeluarkan untuk transportasi dan tidak menyita waktu untuk mengantri tanpa harus menutup usaha/toko yang ada sehingga pendapatan mereka akan terus mengalir untuk memenuhi target yang direncanakan. OJK juga telah melakukan sosialisasi bahwa alternatif bagi UMKM untuk menambah modalnya adalah dengan menggunakan peer to peer lending. 
Layanan keuangan digital Indonesia dilaksanakan dengan payung hukum Indonesia oleh Peraturan Otoritas Jasa Keuangan (POJK) Nomor 77/POJK01/2016, tentang Layanan Pinjam Meninjam Uang Berbasis Tekonologi Informasi (LPMUMBTI). OJK mengatur berbagai hal yang harus ditaati oleh penyelenggara bisnis pinjaman dari pengguna ke pengguna, atau yang disebut peer to peer lending. Sehingga pada akhirnya akan melindungi kepentingan konsumen terkait keamanan dana dan data, serta kepentingan nasional terkait pencegahan pencucian uang dan pendanaan terorisme, serta stabilitas sistem keuangan. Per tanggal 31 Mei 2019, perusahaan Fintech Lending yang berizin dan terdaftar di OJK sudah mencapai 115. Seperti, Danamas, Investree, Amartha, Dompet Kilat, KIMO, Tokomodal, dan UangTeman. Perusahaan tersebut merupakan perusahaan yang berizin dan terdaftar di OJK.

Adanya Fintech, memberikan dampak yang cukup besar bagi kalangan Usaha Mikro Kecil dan Menengah (UMKM) dimana sektor UMKM merupakan sektor tulang punggung riil bagi perekonomian Indonesia dan masih belum terlayani dengan baik untuk memenuhi kebutuhan UMKM untuk memperoleh tambahan pinjaman modal usaha. Berkembangnya Fintech di Indonesia memberikan harapan besar pagi pelaku UMKM yang tersebar di 17000 pulau wilayah Indonesia.

\section{Korelasi Fintech UMKM untuk Stabilitas Sistem Keuangan Indonesia}

UMKM turut serta memberikan kontribusi yang lumayan besar terhadap PDB (Produk Domestik Bruto) Indonesia yaitu 36.82\%. jika dibandingkan dengan indikator yang lain dalam penentuan pemberian kontribusi terhadap pertumbuhan perekonomian Indonesia maka angka tersebut sangat besar. Selain hal tersebut, sebanyak $98.7 \%$ usaha warga Indonesia merupakan usaha Mikro. Maka, dengan jumlah tersebut UMKM dapat menyerap $89.17 \%$ tenaga kerja domestik menurut Wakil Ketua Komite Ekonomi dan Industri Nasional (Arif Budimanta, 2019). Pada tahun 2017, UMKM yang sudah go online sebanyak $7.7 \%$ dan pada 2019 ditargetkan 8\% pada tahun sebelumnya UMKM sudah memberikan kontribusi yang cukup besar bagi pertumbuhan perekonomian Indonesia. 
maka tidak dapat di pungkiri tahun selanjutnya kontribusi dari UMKM juga akan meningkat seiring dengan meningkatnya pelaku UMKM yang go online dimana pendapatan akan meningkat bahkan sampai $80 \%$ (Delloite, 2015). UMKM dapat menjadi tulang punggung perekonomia Indonesia serta dapat meringankan tugas negara untuk mengentaskan kemiskinan dan meningkatkan nilai pendapatan perkapita daerah hingga personal. Maka pada akhirnya akan menstabilkan sistem keuangan Indonesia.

Stabilitas sistem keuangan merupakan suatu kondisi yang memungkinkan sistem keuangan nasional berfungsi secara efektif dan efisien serta mampu bertahan terhadap guncangan internal dan eksternal sehingga alokasi suberdana pendanaan atau pembiayaan dapat berkontribusi pada pertumbuhan dan stabilitas perekonomian nasional (PBI 16/11/PBI/2014 tentang Pengaturan dan Pengawasan Makroprudensial). Pentingnya menjaga stabilitas sistem keuangan negara, dibutuhkan sebuat kebijakan untuk memeliharanya. Kebijakan tersebut disebut kebijakan makroprudensial. Kebijakan makroprudential mempunyai fokus pada risiko dalam sistem keuangan secara keseluruhan, tidak hanya berfokus pada risiko masing-masing individu pelaku keuangan (Bank Indonesia).

Pengalaman krisis ekonomi tahun 1998, Bank Indonesia selaku otoritas pengelola moneter menempuh upaya preventif dengan memberlakukan prinsip kehati-hatian pada sistem keuangan untuk menjaga keseimbangan antara tujuan makroekonomi dan mikroekonomi (Kebiajakan Makro Preudensial). Demi mewujudkan tujuan macroprudential dibutuhkan keseimbangan dalam sistem keungan yang berarti pelaku ekonomi di sistem keuangan harus stabil dan tahan terhadap krisis, maka disinilah pelaku usaha sangat dibutuhkan terutaman pelaku UMKM. Hal ini disebabkan UMKM merupakan usaha yang apling dekat dengan masyarakat umum. Adanya peran UMKM akan mengurangi risiko sistemik dan risiko konsentrasi karena modal usaha UMKM lebih kecil 
sehingga risiko konsentrasi tidak terlalu berdampak pada saat krisis.

Pelaku usaha 59.2 Juta dari \pm 265 juta jiwa, mempunyai pangsa pasar dan keuntungan usaha yang menjanjikan maka jika 1 UMKM saja mampu merekrutnya calon pekerja 1 orang, maka tidak bisa dibayangkan betapa majunya negara indonesia, seberapa besarnya kontribusi pelaku usaha untuk menstabilakn sistem keungan indonesia. Membukan lapangan pekerjaan bagi masyarakat umum, akan membuat pelaku usaha dan masyarakat akan lebih sejahtera sehingga akan memiliki daya beli untuk memenuhi kebutuhan rumah tangga, menyimpan di bank, bahkan membeli saham atau produk investasi dari lembaga keuangan. Srtuktur sistem keuangan akan seimbang antara pelaku dengan modal besar dan pengusaha dengan skala kecil.

\section{Gap/Masalah yang dihadapi oleh pelaku UMKM}

Adapun permasalahan yang dihadapi oleh pelaku UMKM sebagai berikut:

1. Service bank konvensional belum maksimal sehingga dibutuhkan pelayanan yang lebih optimal.

2. Peer to Peer Lending yang belum pasti kerahasiaannya dan sanki bagi pelanggar.

3. Sosialisasi pinjaman online yang belum sampai kepada masyarakat secara menyeluruh, sehingga masyarakat masih ragu dan bingung untuk meminjam kepada entitas yang seperti apa, jaminan apa yang akan diperoleh nasabah Fintech, serta keamanan identitas pribadi aman ataukah tidak.

4. Regulasi Fintech belum jelas dan belum pasti adanya.

\section{Kesimpulan}

Penggunaan Fintech UMKM akan sangat membantu negara untuk meningkatkan pertumbuhan perekonomian Indonesia sehingga akan mampu menstabilkan sistem keuangan Indonesia. Akan tetapi, perlindungan terhadap penggguna Fintech belum maksimal sehingga dibutuhkan kebijakan-kebijakan yang sesuai dan ketat untuk melindungi perusahaan Fintech dan pelaku usaha 
UMKM sebagai nasabah.

\section{DAFTAR PUSTAKA}

Dhar, V., Stein, R. M, Fintech platforms and strategy. Communication of the ACM: 2017, 32-35. (1392-4376-1-PB)

Nicolleti, Bernardo. 2017. The Future of Fintech. Spinger International Publishing AG. Switzerland.

PBI 16/11/PBI/2014 tentang Pengaturan dan Pengawasan Makroprudensial

Peraturan Otoritas Jasa Keuangan (POJK) Nomor 77/POJK01/2016

Philippon, T. 2016. The Fintech Opportunity. NBER working paper 22476.

Undang- Undang Nomor 20 Tahun 2008 tentang Usaha Mikro, Kecil dan Menengah 